\title{
Contribution to the bats knowledge of the Pacaya Samiria National Reserve, Loreto, Peru (Mammalia Chiroptera)
}

\author{
Roberto Toffoli', Giovanni Boano',Anna Bonardi', Massimo Evangelista', Marco Pavia ${ }^{2}$ \& Fabrizio Silvano ${ }^{3}$ \\ ${ }^{1}$ Museo Civico di Storia Naturale, Via S. Francesco di Sales 188, 10022 Carmagnola, Torino, Italy \\ ${ }^{2}$ Dipartimento di Scienze della Terra, Università degli Studi di Torino, Via T. Valperga Caluso 35, 10125 Torino, Italy \\ ${ }^{3}$ Museo Civico di Storia Naturale, Via Aldo Fossati 2, 15060 Stazzano, Alessandria, Italy \\ *Corresponding author, e-mail: rtoffoli@iol.it
}

ABSTRACT

Bats species richness (Mammalia Chiroptera) in Neotropical localities is generally higher than that of any other group of mammals. Surveys of local bat assemblages may provide useful data for conservation management plans. This paper presents bat records based on a chiropterological collection obtained during a preliminary multi-taxa survey (ECOMUSA Project) conducted by the Museo di Storia Naturale di Carmagnola (Torino, Italy) and the Universidad Nacional de la Amazonia Peruana, Iquitos (Loreto, Peru) in the Pacaya Samiria National Reserve (PSNR), where information on bats are scarce, with the aim of contributing a preliminary check of the bats listed between the Marañon, Ucayali, and Amazon rivers south of Iquitos. The survey was conducted from March 14 to March 24, 2002, in two sites of the PSNR. 74 bats of 19 species (18 Phyllostomidae, 1 Emballonuridae) were collected. The most collected species was Sturnira lilium, which makes up $28 \%$ of the captured bats, followed by Carollia perspicillata. In general, the composition of the bat community detected during this short survey in PSNR corresponds to the typical composition of neotropical rainforests. Despite the short duration of the survey, the collected data contributes to the knowledge of bats in PSNR and in the area between the Marañon, Ucayali, and Amazon rivers south of Iquitos, and represents the first record of Rhynchonycteris naso in this area.

KEY WORDS Chiroptera; Neotropical bats; Peruvian Amazon Forest.

Received 25.09.2018; accepted 01.11.2018; printed 30.12.2018; published online 07.01.2019

\section{INTRODUCTION}

With more than 1,300 extant species, bats (Chiroptera) form the second largest mammalian order (Voigt \& Kingston, 2016) and constitute the greatest diversity of mammals (Sosa et al., 2008). Within the neotropical region, Peru is one of the countries with the greatest bat diversity with its 165 species (Pacheco et al., 2009). Of these, 97 species are reported in the Loreto province (Fernández-Arellano \& Torres-Vásquez, 2013), where the area around Iquitos, along the Marañón and
Ucayali rivers, is one of the most studied (Ascorra et al., 1993; Klingbeil \& Willig, 2010; Mori et al., 2012; Fernández-Arellano \& Torres-Vásquez, 2013).

The Pacaya-Samiria National Reserve (PSNR) is the largest protected area in the Peruvian Amazon, covering over 2 million hectares. It is located south of the Amazon/Marañon River, and east of the Ucayali, which are two important biogeographical barriers. Nevertheless, the information about bats in the PSNR is scarce and related mainly to museum specimens (Ruelas, 2017). 
This paper presents bat records based on a chiropterological collection obtained during a preliminary multi-taxa survey (ECOMUSA Project) conducted by the Museo di Storia Naturale di Carmagnola (Torino, Italy) and the Universidad Nacional de la Amazonia Peruana, Iquitos (Loreto, Peru) in the Pacaya Samiria National Reserve (PSNR).

The purpose of this paper is to contribute to a preliminary check of the list of bats between the Marañón, Ucayali, and Amazon Rivers south of Iquitos.

\section{MATERIAL AND METHODS}

\section{Study area}

The survey was conducted from March 14 to March 24, 2002 in two sites (XX de Enero and Yarina) in the Pacaya Samiria National Reserve (Loreto, Peru), along the Rio Yanayacu-Pucate (Fig. 1).

XX de Enero (439'S, $73^{\circ} 49^{\prime} \mathrm{W} ; 102 \mathrm{~m}$ a.s.l., March 14 and March 21-24). This is a small village on the right bank of the Rio Yanayacu-Pucate, about $1 \mathrm{~km}$ upstream from its confluence with the Marañón River. Habitats near the village where field work was conducted include orchards rather degraded varzea forest behind the village, flooded varzea forest (surveyed by canoe), and flooded $\mathrm{Ce}$ cropia dominated second growth.

Yarina $\left(4^{\circ} 45^{\prime} \mathrm{S}, 73^{\circ} 59^{\prime} \mathrm{W}\right.$; $110 \mathrm{~m}$ a.s.1., March 15-21). This is another small village on the right bank of the Yanayacu-Pucate, about $20 \mathrm{~km}$ upstream from XX de Enero. Human impact is much more limited here, and there are no other settlements on the Yanayacu-Pucate upstream from Yarina. Most of the field work here was concentrated in varzea and transitional forest, about $1 \mathrm{Km}$ south of the village.

\section{Data collection and analysis}

Bats were captured in mist nets set from ground level to 2.5 meters high, similarly to those used mainly for ornithological research (Janni et al., 2008). Mist-net lines of 10-20 nets (using 12-meter nets) spaced about 50 meters each, were open at dawn, closed rapidly after sunset, and were used for a total of 570 net-hours at Yarina and 300 net-hours at XX de Enero. Field work was carried out under a specific permit from the "Instituto Nacional de Recursos Naturales, Ministero de Agricultura, Re- publica del Perù" $\mathrm{n}^{\circ} 01 \mathrm{C} / \mathrm{C}-2002-$ INRENADGANP of the $12 / 3 / 02$. The zoological specimens are held in the Museo Civico di Storia Naturale of Carmagnola, Italy (MCCI) and at the Universitad de la Amazonia Peruana, Peru (UNAP).

This work is based only on voucher specimens preserved in MCCI for which a clear identification was possible, while the bats captured and subsequently released were excluded, because identification was uncertain in the field.

Specimens preserved were sexed and identified using mainly Lopez-Baucells et al. (2016) integrated with Aguirre et al. (2009) and Diaz et al. (2011). For the species of the genus Carollia Gray, 1838 the indication provided by Ruelas (2017) was used. For each bat, the following biometric measurements used for identification were taken: forearm, fifth finger, and tibia. For the specimens of the Carollia genera, given the difficulty of identification, the upper molar canine length was also measured.

When possible, the reproductive status of the captured females was assessed through observation of the nipples (Racey, 2009).

The data of this work has been integrated with similar research conducted within a radius of 100 $\mathrm{km}$ from the investigated locations (Klingbeil \& Willig, 2010; Díaz, 2011; Mori et al., 2012; LinaresPalomino et al., 2013; Fernández-Arellano \& Torres-Vásquez, 2013), in order to provide a preliminary bat checklist of the Marañón, Ucayali, and Amazon River areas south of Iquitos.

\section{RESULTS}

The examined specimens represent 19 species of bats (18 Phyllostomidae, 1 Emballonuridae), 34 males and 40 females (Table 1). Phyllostomidae are represented by five subfamilies: Carolliinae, Glossophaginae, Lonchophyllinae, Phyllostominae, and Stenodermatinae. In Yarina, 17 species were detected, while at XX de Enero, only 7 were detected (Table 1). This difference it possibly due to the lower sampling effort carried out in the last locality. The most captured species has been Sturnira lilium, which makes up $28 \%$ of the captured bats, followed by Carollia perspicillata. Of the other species, only single individuals have been captured.

Of the 40 females captured, 17 were evidently lactating (42\%) and presented nipples highlighting an active reproductive status. This is particularly 
evident for Sturnira lilium captured in Yarina, highlighting the presence of a reproductive site in the immediate vicinity of the place of capture.

Most of the species caught have a frugivorous $\operatorname{diet}$ (Table 1), while four have an insectivorous diet (gleaning animalivore) and two nectar-based (Glossophaga soricina, Lonchophylla thomasi).

\section{DISCUSSION}

The relatively brief duration of the survey allowed us only a preliminary assessment of the bats of the area, and the list compiled is very incomplete. The 19 species detected correspond to $27 \%$ of the species known in the Marañón, Ucayali area (Klingbeil \& Willig, 2010; Díaz, 2011; Mori et al., 2012; LinaresPalomino et al., 2013; Fernández-Arellano \& TorresVásquez 2013) and $29 \%$ of the species detected in similar habitats near Iquitos (Hice et al., 2004).
In general, the composition of the bat community detected during this short survey in PSNR corresponds to the typical composition of neotropical rainforests, where Carollia perspicillata, Carollia brevicauda, and Sturnira lilium are the most abundant species (Hice et al., 2004). In particular, $C$. perspicillata is the most captured bat along Río Ucayali (Mori et al., 2012).

Species richness and the abundance of frugivorous and insectivorous bats were clearly in favour of the former. The low abundance of insectivores could be attributed partially to a sampling bias, as some insectivorous species are particularly difficult to capture in mist nets because of their characteristic high and fast flight or their ability to avoid mist nets (Hice et al., 2004). This fact, together with flight behaviour at a high altitude, could also explain the almost total absence of captures of individuals of the families Vespertilionidae and in particular Molossi-

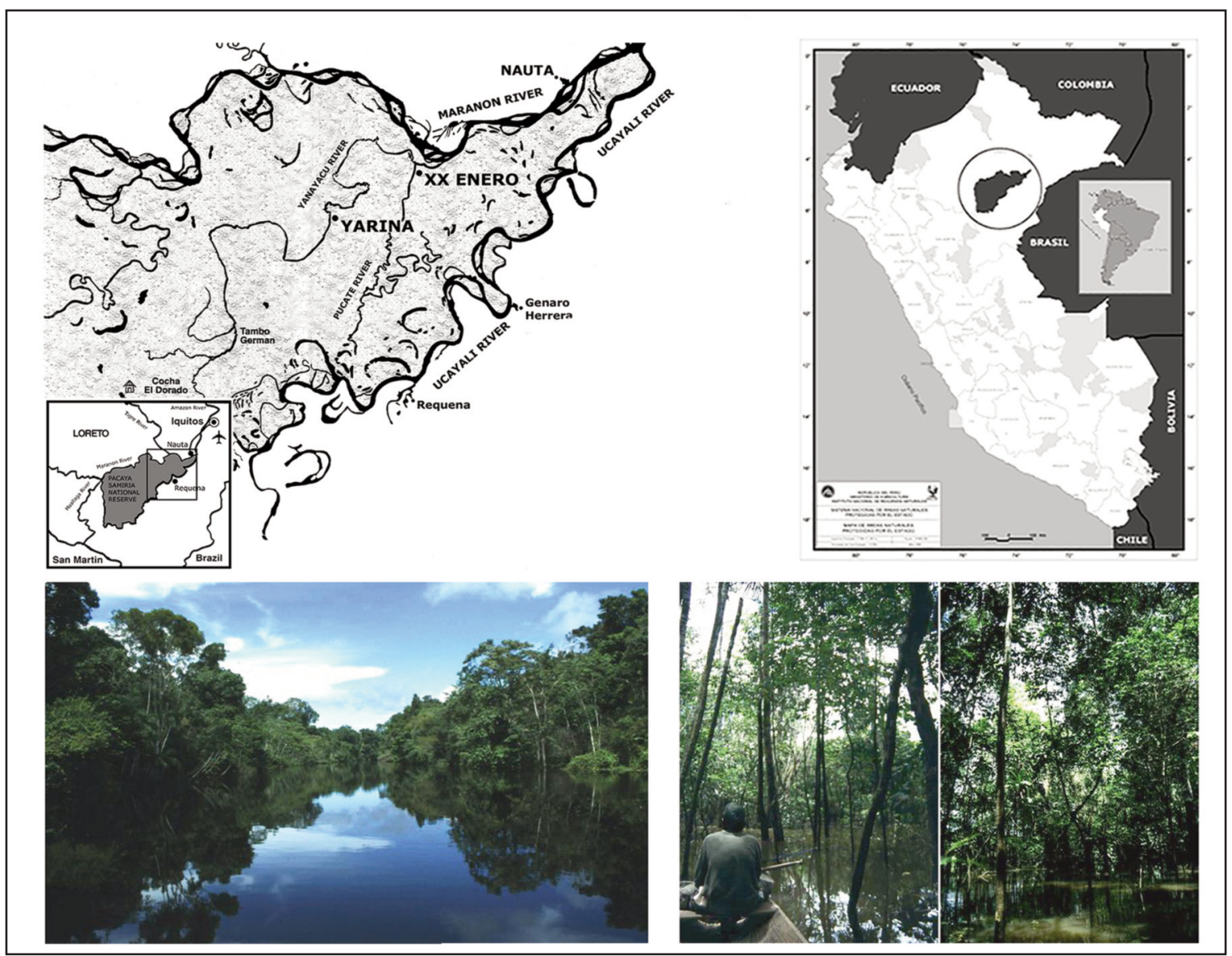

Figure 1. Map of the Rio Yanayacu-Pucate with the localization of Yarina and XX de Enero and view of the Rio Yanayacu-Pucate and flooded varzea forest close to XX de Enero. 


\begin{tabular}{|c|c|c|c|c|c|c|c|}
\hline \multirow[b]{2}{*}{ Species } & \multicolumn{3}{|c|}{$\mathrm{XX}$ de Enero } & \multicolumn{3}{|c|}{ Yarina } & \multirow[b]{2}{*}{ Guild } \\
\hline & Male & Female & Total & Male & Female & Total & \\
\hline \multicolumn{8}{|c|}{ Emballonuridae - Emballonurinae } \\
\hline Rhynchonycteris naso & & & & 1 & 1 & 2 & GA \\
\hline \multicolumn{8}{|l|}{ Phyllostomidae - Phyllostominae } \\
\hline Phyllostomus elongatus & & & & 1 & 1 & 2 & GA \\
\hline Tonatia saurophila & & & & & 1 & $\mathbf{1}$ & GA \\
\hline Trachops cirrhosus & & & & & 1 & $\mathbf{1}$ & GA \\
\hline \multicolumn{8}{|c|}{ Phyllostomidae - Glossophaginae } \\
\hline Glossophaga soricina & & & & & 1 & $\mathbf{1}$ & $\mathrm{N}$ \\
\hline \multicolumn{8}{|c|}{ Phyllostomidae - Lonchophyllinae } \\
\hline Lonchophylla thomasi & & & & 2 & & 2 & $\mathrm{~N}$ \\
\hline \multicolumn{8}{|l|}{ Phyllostomidae - Carolliinae } \\
\hline Carollia brevicauda & 1 & & $\mathbf{1}$ & 1 & 1 & 2 & $\mathrm{~F}$ \\
\hline Carollia castanea & & & & 3 & 1 & 4 & $\mathrm{~F}$ \\
\hline Carollia perspicillata & & 3 & 3 & 1 & 5 & 6 & $\mathrm{~F}$ \\
\hline \multicolumn{8}{|c|}{ Phyllostomidae - Stenodermatinae } \\
\hline Artibeus anderseni & 1 & & 1 & & & & $\mathrm{~F}$ \\
\hline Artibeus obscurus & 1 & & 1 & 4 & & 4 & $\mathrm{~F}$ \\
\hline Artibeus planirostris & 1 & & 1 & 2 & 3 & 5 & $\mathrm{~F}$ \\
\hline Dermanura glauca & & & & 1 & & 1 & $\mathrm{~F}$ \\
\hline Mesophylla macconnelli & & & & 2 & 1 & 3 & $\mathrm{~F}$ \\
\hline Platyrrhinus brachycephalus & 1 & & $\mathbf{1}$ & 1 & 3 & 4 & $\mathrm{~F}$ \\
\hline Sturnira lilium & & & & 6 & 15 & 21 & $\mathrm{~F}$ \\
\hline Sturnira tildae & & & & 4 & 1 & 5 & $\mathrm{~F}$ \\
\hline Uroderma bilobatum & & 1 & $\mathbf{1}$ & & & & $\mathrm{F}$ \\
\hline Uroderma magnirostrum & & & & & 1 & $\mathbf{1}$ & $\mathrm{F}$ \\
\hline Specimens collected & & & 9 & & & 65 & \\
\hline Species & & & 7 & & & 17 & \\
\hline
\end{tabular}

Table 1. List of sampled bats by sex and diet guild: F frugivore, GA gleaning animalivore, N nectarivore.

dae. The ratio of the captures of the different guilds corresponds to their detectability by catching with mist nets on the ground (Meyer et al., 2011).

The number of lactating females corresponds to that observed in other areas of neotropical rainforests (Hice et al., 2004), and a similar pattern is commonly observed in neotropical phyllostomid frugivorous bats (Willig, 1985a; 1985b).

Despite the short duration of the survey and the lack of other sampling techniques that could have increased species richness (e.g., canopy nets, acoustic sampling, etc.) as indicated by Meyer et al. (2011), the collected data contribute to the knowledge of bats in PSNR and in the area between the Marañón, Ucayali, and Amazon rivers south of Iquitos. These, integrated with the bibliographic information available (Klingbeil \& Willig, 2010; Díaz, 2011; Mori et al., 2012; Fernández-Arellano \& Torres-Vásquez 2013; Linares-Palomino et al.,
2013) within a buffer of $100 \mathrm{~km}$ from the sampled sites, provide a checklist of 72 species of bats (Table 2). Although the species detected during this brief survey are already known in the bibliography for the area, the data collected in this survey added a species, not previously reported (Rhynchonycteris naso), to the checklist of the buffer area. The presence of this species has recently been confirmed in the buffer area by an observation in February 2016 (https://www.inaturalist.org/observations/ 3350987).

Finally, more detailed investigations are still desirable using different sampling techniques (Meyer et al., 2011) to better define the status of data deficient species (e.g. Peropteryx pallidoptera, Carollia benkeithi, Myotis simus), but above all to better define the biodiversity of bats in the area, considering the recent description of new bat species in Loreto Departement (Simmons et al., 2002). 


\begin{tabular}{|c|c|}
\hline species & IUCN \\
\hline EMBALLONURIDAE - EMBALLONURINAE & \\
\hline Cormura brevirostris (Wagner, 1843) & $\overline{\mathrm{LC}}$ \\
\hline Diclidurus albus (Wied-Neuwied, 1820) & $\mathrm{LC}$ \\
\hline Peropteryx macrotis (Wagner, 1843) & $\mathrm{LC}$ \\
\hline $\begin{array}{l}\text { Peropteryx pallidoptera Lim, Engstrom, Reid, } \\
\text { Simmons, Voss et Fleck, } 2010\end{array}$ & DD \\
\hline Rhynchonycteris naso (Wied-Neuwied, 1820) & $\mathrm{LC}$ \\
\hline Saccopteryx leptura (Schreber, 1774) & $\mathrm{LC}$ \\
\hline PHYLLOSTOMIDAE - MICRONYCTERINAE & \\
\hline $\begin{array}{l}\text { Micronycteris matses (Simmons, Voss et Fleck, } \\
\text { 2002) }\end{array}$ & $\mathrm{DD}$ \\
\hline Micronycteris megalotis (Gray, 1842) & $\mathrm{LC}$ \\
\hline Micronycteris minuta (Gervais, 1856) & LC \\
\hline PHYLLOSTOMIDAE - DESMODONTINAE & \\
\hline Desmodus rotundus (É. Geoffroy, 1810) & $\mathrm{LC}$ \\
\hline PHYLLOSTOMIDAE - PHYLLOSTOMINAE & \\
\hline Chrotopterus auritus (Peters, 1856) & $\mathrm{LC}$ \\
\hline Lophostoma brasiliense Peters, 1866 & LC \\
\hline Lophostoma carrikeri (Allen, 1910) & LC \\
\hline Lophostoma silvicolum D'Orbigny, 1836 & $\mathrm{LC}$ \\
\hline Mimon crenulatum (É. Geoffroy, 1803) & $\mathrm{LC}$ \\
\hline Phylloderma stenops (Peters, 1856) & LC \\
\hline Phyllostomus elongatus (É. Geoffroy, 1810) & $\mathrm{LC}$ \\
\hline Phyllostomus hastatus (Pallas, 1767) & $\overline{\mathrm{LC}}$ \\
\hline Tonatia saurophila Koopman et Williams, 1951 & LC \\
\hline Trachops cirrhosus (Spix, 1823) & $\mathrm{LC}$ \\
\hline Vampyrum spectrum (Linnaeus, 1758) & $\overline{\mathrm{LC}}$ \\
\hline PHYLLOSTOMIDAE - GLOSSOPHAGINAE & \\
\hline Anoura caudifer (É. Geoffroy, 1818) & LC \\
\hline Choeroniscus minor (Peters, 1868) & $\mathrm{LC}$ \\
\hline Glossophaga soricina (Pallas, 1766) & $\mathrm{LC}$ \\
\hline PHYLLOSTOMIDAE - LONCHOPHYLLINAE & \\
\hline Lionycteris spurrelli Thomas, 1913 & $\mathrm{LC}$ \\
\hline Lonchophylla thomasi J.A. Allen, 1904 & $\mathrm{LC}$ \\
\hline PHYLLOSTOMIDAE - CAROLLIINAE & \\
\hline Carollia benkeithi Solari et Baker, 2006 & $\overline{\mathrm{DD}}$ \\
\hline Carollia brevicauda $($ Schinz, 1821) & $\mathrm{LC}$ \\
\hline Carollia castanea (H. Allen, 1890) & $\mathrm{LC}$ \\
\hline Carollia perspicillata (Linnaeus, 1758) & $\mathrm{LC}$ \\
\hline PHYLLOSTOMIDAE - “GLYPHONYCTERINAE”' & \\
\hline Glyphonycteris daviesi (Hill, 1964) & $\mathrm{LC}$ \\
\hline Glyphonycteris sylvestris Thomas, 1896 & $\mathrm{LC}$ \\
\hline Trinycteris nicefori (Sanborn, 1949) & LC \\
\hline PHYLLOSTOMIDAE - "RHINOPHYLLINAE" & \\
\hline Rhinophylla fischerae Carter, 1966 & LC \\
\hline
\end{tabular}

\begin{tabular}{|c|c|}
\hline species & IUCN \\
\hline Rhinophylla pumilio Peters, 1865 & $\mathrm{LC}$ \\
\hline PHYLLOSTOMIDAE - STENODERMATINAE & \\
\hline Artibeus anderseni (Osgood, 1916) & $\mathrm{LC}$ \\
\hline Artibeus bogotensis K. Andersen, 1906 & $\mathrm{NE}$ \\
\hline Artibeus cinereus (Gervais, 1856) & $\mathrm{LC}$ \\
\hline Artibeus concolor Peters, 1865 & $\mathrm{LC}$ \\
\hline Artibeus gnomus (Handley, 1987) & $\mathrm{LC}$ \\
\hline Artibeus lituratus (Olfers, 1818) & $\mathrm{LC}$ \\
\hline Artibeus obscurus (Schinz, 1821) & $\mathrm{LC}$ \\
\hline Artibeus planirostris (Spix, 1823) & $\mathrm{LC}$ \\
\hline Artibeus watsoni (Thomas, 1901) & $\mathrm{LC}$ \\
\hline Chiroderma trinitatum Goodwin, 1958 & $\mathrm{LC}$ \\
\hline Chiroderma villosum Peters, 1860 & $\mathrm{LC}$ \\
\hline Dermanura glaucus (Thomas, 1893) & $\mathrm{LC}$ \\
\hline Dermanura gnomus (Handley, 1987) & $\mathrm{LC}$ \\
\hline Mesophylla macconelli Thomas, 1901 & $\mathrm{LC}$ \\
\hline $\begin{array}{l}\text { Platyrrhinus brachycephalus (Rouk et Carter, } \\
\text { 1972) }\end{array}$ & $\mathrm{LC}$ \\
\hline Platyrrhinus helleri (Peters, 1866) & $\mathrm{LC}$ \\
\hline Platyrrhinus infuscus (Peters, 1880) & $\mathrm{LC}$ \\
\hline Sturnira lilium (É. Geoffroy, 1810) & $\mathrm{LC}$ \\
\hline Sturnira magna de la Torre, 1966 & $\mathrm{LC}$ \\
\hline Sturnira tildae de la Torre, 1959 & $\mathrm{LC}$ \\
\hline Uroderma bilobatum Peters, 1866 & $\mathrm{LC}$ \\
\hline Uroderma magnirostrum Davis, 1968 & $\mathrm{LC}$ \\
\hline Vampyressa bidens (Dobson, 1878) & $\mathrm{LC}$ \\
\hline Vampyressa brocki (Peterson, 1968) & $\mathrm{LC}$ \\
\hline Vampyressa thyone Thomas 1909 & $\mathrm{LC}$ \\
\hline Vampyriscus bidens (Dobson, 1878) & $\mathrm{LC}$ \\
\hline Vampyrodes caraccioli (Thomas, 1889) & $\mathrm{LC}$ \\
\hline NOCTILIONIDAE & \\
\hline Noctilio albiventris Desmarest, 1818 & $\mathrm{LC}$ \\
\hline MOLOSSIDAE - MOLOSSINAE & \\
\hline Cynomops planirostris (Peters, 1866) & $\mathrm{LC}$ \\
\hline Eumops maurus (Thomas, 1901) & $\mathrm{DD}$ \\
\hline Molossus coibensis Allen, 1904 & DD \\
\hline Molossus molossus (Pallas, 1766) & $\mathrm{LC}$ \\
\hline Molossus rufus E. Geoffroy, 1805 & $\mathrm{LC}$ \\
\hline VESPERTILIONIDAE - MYOTINAE & \\
\hline Myotis nigricans (Schinz, 1821) & $\mathrm{LC}$ \\
\hline Myotis riparius Handley, 1960 & $\mathrm{LC}$ \\
\hline Myotis simus Thomas, 1901 & DD \\
\hline THYROPTERIDAE & \\
\hline Thyroptera lavali (Pine, 1993) & DD \\
\hline
\end{tabular}

Table 2. Checklist of the bats of the Marañón, Ucayali, and Amazon rivers south of Iquitos and their IUCN status: $\mathrm{LC}=$ Least Concern, NE = Not Evaluated, DD = Data Deficient. 


\section{ACKNOLEDGEMENTS}

We want to thank the Instituto Nacional Recursos Naturales (INRENA) of the Republic of Perù for research and export permits, the deceased Mario de Col and all his coworkers (Green Life) for their invaluable logistical support, Giuliana Del Papa of the Italian Embassy for logistic support, Carlos Rivera (UNAP), Alberto Tamietti (Parco del Po, Torino, Italy), Ottavio Janni (Piedimonte Matese, Caserta, Italy), and Stefano Zucca (Parco del Po, Torino, Italy) for their help with field work, and Franco Bernini (University of Pavia, Italy) for help with lab work, and the communities of XX de Enero and Yarina for their hospitality and collaboration. We also would like to thank Luciano Demagistris (Pieve a Nievole, Pistoia, Italy), the Cave Germaire S.p.a. and the Rotary Club Moncalieri (Torino, Italy) for their financial support.

\section{REFERENCES}

Aguirre L.F., Vargas A. \& Solari S., 2009. Clave de campo para la identificación de los murciélagos de Bolivia. Centro de Estudios en Biología Teórica y Aplicada. Cochabamba, Bolivia, 38 pp.

Ascorra C.F., Gorchov D.L. \& Cornejo F., 1993. The bats from Jenaro Herrera, Loreto, Peru. Mammalia, 57: 533-552.

Díaz M.M., 2011. New records of bats from the northern region of the Peruvian Amazon. Zoological Research, 32: $168-178$.

Díaz M.M., Aguirre L.F. \& Barquez R.M., 2011. Clave de identificación de los murciélagos del cono sur de Sudamérica. Centro de Estudios en Biología Teórica y Aplicada. Cochabamba, Bolivia, 94 pp.

Fernández-Arellano G.J. \& Torres-Vásquez M.I., 2013. Lista actualizada de quirópteros de los Departamentos de Loreto Ucayali y Madre de Dios (Perú). Barbastella, 6: 73-88.

Hice C.L., Velazco P.M. \& Willig M.R., 2004. Bats of the Reserva Nacional Allpahuayo-Mishana, northeastern Peru, with notes on community structure. Acta Chiropterologica, 6: 319-334.

Janni O., Boano G., Pavia M. \& Silvano F., 2008. A preliminary avifaunal survey along the Rio YanayacuPucate, Pacaya Samiria National Reserve, Loreto, Peru. Memoirs on Biodiversity, 1: 483-496.

Linares-Palomino R., Chávez G., Pérez E., Takano F., Zamora H., Deichmann J.L. \& Alonso A., 2013. Patrones de diversidad y composición en comunidades de pteridophyta, aves, anfibios, reptiles y murciélagos en la cuenca del rio Tapiche, Loreto. In: LinaresPalomino R., Deichmann J.L. \& Alonso A. (Eds.), Biodiversidad y uso de recursos naturales en la cuenca baja del río Tapiche. Instituto de Investigaciones de la Amazonia Peruana, pp. 14-55.

Lopez-Baucells A., Rocha R., Bobrowiec P.E.D., Palmeirim J.M. \& Meyer C.F.J., 2016. Field guide to Amazonian bats. Ed. INPA, 173 pp.

Klingbeil B.T. \& Willig M.R., 2010. Seasonal differences in population ensemble and community level responses of bats to landscape structure in Amazonia. Oikos, 119: 1654-1664.

Meyer C.F., Aguiar L., Aguirre L.F., Baumgarten J., Clarke F.M., Cosson J.F. \& Henry M., 2011. Accounting for detectability improves estimates of species richness in tropical bat surveys. Journal of Applied Ecology, 48: 777-787.

Mori S., Huamaní L. \& Cadenillas R., 2012. Murciélagos de la Cuenca Baja del Río Ucayali, Loreto, Perú. Abstract I Simposio Peruano de Murciélagos.

Pacheco V., Cadenillas R. \& Salas E., 2009. Diversidad y Endemismo de los Mamíferos del Perú. Revista Peruana de Biología, 16:5-32. DOI: 10.15381/rpb. v16il.111

Racey P.A., 2009. Reproductive assessment of bats. Ecological and behavioural methods in the study of bats In: Kunz T.H. \& Parson S., Ecological and behavioral methods for the study of bats. Johns Hopkins University Press, Baltimore, pp. 249-264.

Ruelas D., 2017. Diferenciación morfológica de Carollia brevicauda y C. perspicillata (Chiroptera: Phyllostomidae) de Perú y Ecuador. Revista Peruana de Biología, 24: 363-382.

Simmons N.B., Voss R.S. \& Fleck D.W., 2002. A new Amazonian species of Micronycteris (Chiroptera: Phyllostomidae) with notes on the roosting behavior of sympatric congeners. American Museum Novitates, 3358: 1-16.

Sosa V.J., Hernández-Salazar E., Hernández-Conrique D. \& Castro-Luna A.A., 2008. Murciélagos. In: Manson R.H., Hernández-Ortíz V., Gallina S. \& Mehltreter K., Agroecosistemas cafetaleros de Veracruz: biodiversidad, manejo y conservación. Instituto de Ecología A.C. (INECON) e Instituto Nacional de Ecología (INE-SEMAR-NAT), México: 181-192.

Voigt C.C. \& Kingston T., 2016. Bats in the Anthropocene: conservation of bats in a changing world (Vol. 606). New York: SpringerOpen, 606 pp. DOI: 10.1007/978-3-319-25220-9_1.

Willig M.R., 1985a. Reproductive activity of female bats from northeastern Brazil. Bat Research News, 26: 17-20.

Willig M.R., 1985b. Reproductive patterns of bats from caatingas and cerrado biomes in northeast. Brazil. Journal of Mammalogy, 66: 668-681. 